811.163.41'367.4

https://doi.org/10.18485/sj.2018.23.1.6

МИЛОШ М. КОВАЧЕВИһ *

Филолошки факултет Београд

Филолошко-уметнички факултет Крагујевац
Оригинални научни рад

Примљен: 04. 01. 2018.

Прихваћен: 29. 01. 2018.

\title{
СИНОНИМНОСТ ПАДЕЖНИХ ОПОЗИТНИХ КОНСТРУКЦИЈА У СРПСКОМ ЈЕЗИКУ**
}

\begin{abstract}
У раду се, на богатом корпусу из новинарског подстила публицистичког стила савременог српског језика, пописују и описују модели падежних синтагми којима се у српском језику може изразити нереципрочно опозитно значење. Анализа тих конструкција врши се синонимно-дистрибуцијском методом, што значи да се идентификују и описују контексти који дозвољавају супституентност неке падежне форме генитивом с предлогом против као прототипском и верификаторском формом опозитности.
\end{abstract}

Кључне ријечи: падежне конструкције, значење опозитности, нереципрочна опозитност, синонимност.

\section{1. О ОПОЗИТНОМ ЗНАЧЕЬУ}

Придјев опозитан изведен је од именице латинског поријекла опозит (oppositum), која значи супротност и/или противност. ${ }^{1}$ Логично је стога што

"mkovacevic31@gmail.com

${ }^{* *}$ Рад је настао у оквиру пројекта 178014: Динамика структура савременог српског јези$\kappa a$, који финансира Министарство просвете, науке и технолошког развоја Републике Србије

${ }^{1}$ опозит - (лат. орpositum) 1. супротност, противљење, противуречност, 2. линг. реч која има супротно значење, в. антоним. (Клајн, Шипка 2008: 863); опозит - лат. 1. линг. реч супротног значења, 2. супротност, противност (РМС 1971: 157). Од именице опозит рјечници не биљеже придјевску изведеницу. 
је у значењу сваке опозитне конструкције нужно присутна семантичка компонента супротности. Будући да свака супротност нужно не значи и опозитност, неопходно је издвојити њихову најбитнију диференцијалну особину, а то је социјативност. Социјативноост која подразумијева „повезаност најмање два учесника у извесној заједничкој радњи или стању” (Пипер и др. 2005: 701), с тим да ти учесници не морају бити подударни у погледу нити присуства нити врсте анимативности (могу нпр. подразумијевати однос два човјека, човјека и другог живог бића, човјека и предмета, два предмета и сл.) - јесте нужна карактеристике опозитних а факултативна карактеристика супротних конструкција. Но, будући да свака социјативност није опозитност, потребно је издвојити и критеријум(е) њиховог разграничења. А за основни диференцијални критеријум тих двију категорија може се узети критеријум интенционалног непријатељског дјеловања. Из тога проистиче да се категорија опозитности темељи на структурисаном скупу трију семантичких компоненти: супротности, социјативности и интенционалности. На то посредно упућују и граматичке дефиниције генитивног предлога против као основног опозитног предлога у српском језику². Тако Ј. Силић и И. Прањковић као његово основно значење издвајају супротност, тврдећи да „приједлог против означује супротност међу двама предметима или догађајима" (Силић, Прањковић 2005: 217-218), док П. Пипер и И. Клајн значењски предлог против одређују као „социјативни генитив”, који „долази на питање против кога? а употребљава [се] у адвербијалној, атрибутској или предикатској служби са значењем друштва или реципрочности" (Пипер, Клајн 2013: 344). М. Стевановић, међутим, за овај предлог каже како он служи за означавање „да се води борба против тог [генитивног] појма” (Стевановић 1979: 351), што је заправо друкчије дефинисано значење „непријатељског дјеловања". А ту значењску компоненту овог предлога као основну истиче и К. Фелешко констатујући да је заједничка одлика свих генитивних синтагми с предлогом против то „да означе радњу која је непријатељска у односу на особу (појаву, институцију) означену у именском делу предлошкопадежне конструкције" (Фелешко 1995: 149). Све три семантичке компоненте нужне су компоненте опозитног предлошког значења, али је, чини се, од тих трију компонената компонента „интенционалног непријатељског дјеловања” specifica differentia опозитне категорије у односу на категорије супротности и социјативности. Та компонента служи и за диференцирање двају основних типова опозитног значења. Наиме, на основу тога да ли је компонента „непријатељског дјеловања" карактеристика обају супротстављених учесника, или само једног од њих, разликују се реципрочна и нереципрочна опозитност.

${ }^{2}$ То је једини предлог чије се основно значење, истина само у једном граматичком дјелу, одређује као опозитивно (што је, за разлику од опозитно, творбено несистеман придјевски термин): „ОПОЗИТИВНИ ГЕНИТИВ. То је генитив којим се исказује супротстављање, противљење некога некоме или нечему" (Пипер и др. 2005:175). 
Реципрочна опозитност подразумијева супарнике (такмаце, противнике) који на неки начин желе надвладати један другог, односно међусобно „одмјерити снаге" (нпр.: Срби су се борили против Турака /са Туриима ↔ Турии су се борили против Срба/са Србима), док нереципрочна подразумијева „непријатељску дјелатност" (најчешће човјекову) која се огледа у жељи за сузбијањем или укидањем онога што означава појам именован зависном падежом (нпр.: Радници протестују против мјера штедње $\leftrightarrow *$ *ајере штедње протестују против радника).

Будући да смо у посебном раду детаљно анализирали конструкције реципрочне опозитности освјетљавањем (не)конкурентности генитивне синтагме с предлогом против и инструменталне с предлогом са (Ковачевић 2017: 129-155), у овом раду бавићемо се анализом само падежних конструкција нереципрочне опозитности. У тим конструкцијама „социјативни” појмови су нужно анимативно диференцирани: експлицитни или подразумијевајући вршилац радње обиљежене глаголом или глаголском именицом у надређеном члану синтагме - увијек је човјек, док се појмом у зависном падежу против кога човјек подузима „непријатељско дјеловање” - означава или нешто неживо (што је најчешће резултат човјековог дјеловања) или пак човјека који не предузима контрадјеловање. Основно значење свих нереципрочних опозитних падежних конструкција тако се своди на човјеково подузимање непријатељског дјеловања ради сузбијања или укидања онога што је означено зависним чланом синтагме.

Циљ рада је да се, на богатом корпусу из новинарског подстила публицистичког стила савременог српског језика ${ }^{3}$, попишу и опишу модели падажних синтагми којима се у српском језику може изразити нереципрочно опозитно значење. Анализа тих конструкција биће заправо синонимно-дистрибуцијска, што значи да ће подразумијевати опис „контекста” који дозвољавају супституентност неке падежне форме генитивом с предлогом против као прототипском и верификаторском формом опозитности. То значи да ће предлог против бити верификатор припадности неке падежне конструкције категорији опозитности. Уколико се, наиме, нека падежна конструкција може замијенити генитивном конструкцијом с предлогом против а да се њено основно значење не промијени - онда ту конструкцију сматрамо опозитном.

Верификаторски статус опозитности, синтагмама с генитивним предлогом против, задаје повлашћен статус у систему падежних опозитних синтагми српскога језика. Само предлог против цјелином своје употребе, дакле, у било ком контексту има опозитно значење, док сви други предлози само једним делом своје употребе улазе у поље опозитности. Из тога онда нужно проистиче

${ }^{3}$ Попис извора из којих су ексцерпирани сви примјери што их у овом раду наводимо дат је на крају рада. 
да је предлог против контекстуално неусловљен опозитни предлог, док су сви други предлози којима се може изразити опозитно значење - контекстуално условљени. Из тога онда произлази да између предлога против и осталих опозитних предлога влада хјелмслевљевски схваћен однос детерминације (Хјелмслев 1980: 40): гдје се год може употријебити било који падежни или предлошко-падежни облик у опозитном значењу, ту се може употријебити и генитив с предлогом против, али не и обрнуто: у свим случајевима опозитне употребе предлога против није могућа употреба ниједног другог опозитног падежног облика синтагме. Из тога онда нужно проистиче да је дистрибуција предлога против у опозитном значењу шира од дистрибуције свих других опозитних падежних форми. То онда нужно имплицира постојање контекста у којима је од свих опозитних падежних форми могућа употреба само генитивне форме с предлогом против, као нпр.: Комунистичка партија [je] жестоко деловала против Срба у периоду пре Другог светског рата. (Политика, 10. 9. 2016, 8); Они су навијали против ове земље. (Политика, 23. 8. 2016, 5); Против тог закона је гласало пет посланика (Вечерње новости, 10. 2. 2016, $12)$; ...jер је циљ оних који се боре против референдума укидање РС (Вечерње новости, 1. 9. 2016, 3) и сл.

Пошто је циљ нашега рада синонимија схваћена и као блискозначност супституентних падежних форми, онда се нужно из анализе искључују примјери датога типа, тј. примјери у којима генитив с предлогом против није замјењив ниједном другом падежном формом као синонимом или блискозначницом. А анализу синонимности и/или блискозначности опозитних падежних форми вршићемо тако што ћемо најприје у саоднос доводити предлог против са неким другим предлогом или беспредлошком падежном формом, а након анализе тих бипредлошких синонимнских опозитних форми, анализираћемо моделе исказивања синонимног опозитног значења ${ }^{4}$ полипредлошким и/или полипадежним, дакле најмање морфолошко-лексички троврсним падежним и/или предлошко-падежним формама.

\section{2. МОДЕЛИ СИНОНИМНИХ ОПОЗИТНИХ ПАДЕЖНИХ ФОРМИ}

Свим зависним падежима српскога језика може се изразити опозитно значење, с тим да се само предлошким генитивом, акузативом и локативом изражава опозитност, док се и предлошким и беспредлошким формама датива и инструментала може изразити опозитност. Редосљед анализе падежних и

\footnotetext{
${ }^{4}$ Будући да у језику и не може постојати потпуна или права синонимија (јер је искључује релациони статус елемената у структури система), термин синониман у овоме раду употребљавамо и кад говоримо о блискозначности.
} 
предлошко-падежних опозитних форми подударан је слиједу падежа, зато што тај редосљед (од генитива до локатива) у основи одражава и фреквентност употребе појединих падежа у изражавању опозитних (под)значења.

\section{1. Генитивне предлошко-падежне форме с опозитним значењем}

Генитив од свих падежа има највише опозитних предлошко-падежних форми. Основној опозитној падежној форми - генитиву с предлогом против-у одређеним контекстима синонимне и/или блискозначене могу бити синтагме са сљедећих седам генитивних предлога и предлошких израза: због, поводом, на рачун, на штету, на адресу, од и посл(иј)е.

\subsection{1. ЗБОГ + Г // ПРОТИВ $+\Gamma$}

Од свих падежних и предлошко-падежних конструкција у изражавању нереципрочне опозитности генитиву с предлогом против најконкурентнија је примарно узрочна генитивна падежна конструкција с предлогом због. То и не треба да чуди ако се зна да се и генитивом с предлогом против у одређеним контекстима неретко изражава узрочно значење (в. Ковачевић 1987: 189-195; 2012: 190-191). Уз то, и семантичка категорија опозитности и категорија узрока разлога, који се приоритетно изражава генитивом с предлогом због - међусобно интерферирају зато што у подлози „непријатељског дјеловања” на коме почива опозитност увијек стоји неки разлог везан за појам изражен генитивом. Међутим, опозитност и узрок по многим су критеријумима различите категорије, тако да узрочно због добија вриједност опозитног против само у неким контекстима, с одређеним типом лексема у позицији надређеног и/или подређеног члана синтагме. Због тога, а и ради потврде синонимности, при навођењу примјера даваћемо претворбу једног у други падежни облик у загради са стрелицом, с тим да ћемо у примјерима надређени члан синтагме истицати подвлачењем а зависни курзивно:

(1) Коментаришући митинге због [ $\rightarrow$ против] рушења у Савамали и против $[\rightarrow$ због] смена у РТВ, Вучић је рекао да мисли да амбасадори САД и ЕУ нису имали никакву улогу у њима. (Вечерње новости, 15. 6. 2016, 3); Протест због [ $\rightarrow$ против] градње бензинске пумпе (Политика, 14. 11. 2017, 18: наслов); Протест Косјераца против [ $\rightarrow$ због] спаљивања отпада у цементари (Политика, 15. 11. 2017, 13: наслов); А председник кућног савета није протестовао због [ $\rightarrow$ против] оваковог антиевропског наговарања. (Политика, 4. 9. 2016, 6); Протестовало се $и$ против [ $\rightarrow$ због] најаве напада на медије (Вечерње новости, 2. 2. 2016, 8); Студентске организације и синдикати у Паризу већ четврти дан штрајкују због [ $\rightarrow$ против] најављеног плана реформи. (Политика, 4. 4. $2016,3)$; Шест од укупно осам рафинерија нафте у земљи је обухваћено штрајком због [ $\rightarrow$ против] новог закона о раду. (Вечерње новости, 24. 5. 2016, 9); Док та рошоминијада траје, у Нишу се спремају демонстрације против [ $\rightarrow$ због] споразума са НАТО (Вечерње новости, 28. 2. 2016, 2); Побуна против [ $\rightarrow$ због] судијских одлука није иновација после 
150. вечитог дербија (Вечерње новости, 2. 3. 2016, 38); Немачки бунт против [ $\rightarrow$ због] РТВ претплате (Политика, 9. 4. 2016, 2: наслов); Подигли смо глас и против [ $\rightarrow$ због] некомпетентности чланова комисије (Политика, 19. 5. 2016, 13); Недавно су у Београду одржани митинзи на којима су грађани изразили незадовољство због [ $\rightarrow$ против] лошег стањ у у нашем урбанизму (Вечерње новости, 28. 5. 2016, 26); Голооточани су се бунили због [ $\rightarrow$ против] услова смештаја. А сви су имали собу са погледом на море. (Вечерње новости, 19. 6. 2016, 23: Александар Чотрић); ...сличан пример показује и Ниш, где су се грађани побунили против [ $\rightarrow$ због] партијског кадрирањ $а$ у јавним предузећима (Печат, 10. 6. 2016, 8); Петиција против [ $\rightarrow$ због] образовних закона прослеђена председнику Србије, влади, Народној скупштини (Политика, 30.11. 2017, 8: наслов); Жалба због [ $\rightarrow$ против] обарања листе (Вечерње новости, 28. 3. 2016, 3: наслов); ЕУ мора да реагује због [ $\rightarrow$ против] усташтва (Политика, 3. 8. 2016, 5: наслов); Ниједан од двојице римокатоличких папа или неки од њихових помоћника ни да помисли, а камоли да изусти неку реч осуде због $[\rightarrow$ против] злочина који се над православним Србима чини. (Печат, 10. 6. 2016, 70) и сл.

У свим наведеним примјерима надређени члан синтагме садржи компоненту „непријатељског дјеловања”: то су глаголи, глаголске именице и перифрастички изрази са основним значењем „протеста” (протестовати, протест, (по)бунити се, бунт, штрајковати, итрајк, митинг, жалити се, жалба, реаговати, реаговање, демонстраиије, петиција, изразити незадовољство, дићи глас, изустити реч осуде, и сл). А протест је увијек посљедица разлога израженог зависним чланом, с тим да је циљ протеста да се тај разлог „елиминише”. Неслагање с разлогом тако је предодредило његово укидање као циљ деловања, на чему се и темељи подлога супституентности и блискозначности ових двију конструкција.

\subsection{2. ПОВОДОМ + Г // ПРОТИВ $+\Gamma$}

Повод је подврста разлога. То је „додајни разлог” који потпомаже да, због већ присутних других разлога, у датом моменту дође до реализације посљедице, која би се (будући припремљена другим разлозима) и без њега, повода, десила, али не у том тренутку (Ковачевић 2012: 53-54). Због тога није ни чудо да је генитив с предлошким изразом поводом у опозитном значењу конкурентан генитиву с предлогом против управо у оним контекстима у којима је то и генитив с предлогом због; дакле, уз исти тип глагола, глаголских именица и перифрастичких израза са значењем „протеста”:

(2) Протест поводом [ $\rightarrow$ против] Вучићевог ступања на дужност (Политика, 31. 5 . 2017, 5: наслов); У новобеоградском блоку 45 стотине житеља овог краја протестовало је поводом [ $\rightarrow$ против] почетка градње НИС-ове бензинске пумпе. (Политика, 14. 11. 2017, 18); Исламска заједница Србије ... изражава „одлучно негодовање” поводом [ $\rightarrow$ против] предлога министра просвете Вербића (Политика, 8. 1. 2016, 5); Председник Владе Србије Александар Вучић упутио је јуче протестно писмо поводом [ $\rightarrow$ против] непримереног односа тог суда према нашој земљи. (Политика, 13. 2. 2016, 9); Истичући да не постоји основ за критике поводом [ $\rightarrow$ против] потписивања споразума са НАТО-ом, Николић каже да овде постоје дежурни критичари (Политика, 21. 2. 2016, 4); Поднели смо Уставном суду жалбу поводом [ $\rightarrow$ против] срамне одлуке судије Управног суда (Вечерње новости, 
29. 3. 2016, 3); Србија коначно мора сама да покрене велику и озбиљну медијску и дипломатску кампању поводом [ $\rightarrow$ против] цветања неофашизма и усташлука у Хрватској. (Информер, 1. 8. 2016, 3); Највећи број њих односи се на притужбе поводом [ $\rightarrow$ против] неразумно дугог трајања судских поступака (Политика, 1. 8. 2016, 8) и сл.

Када се размотри лексичка структура опозитних синтагми с предлогом због и предлошким изразом поводом, уочљива је лексичкосемантичка „ограниченост” надређеног и подређеног члана синтагме. надређени члан је увијек нека језичка јединица с општим значењем „протеста”, док се подређеним чланом увијек означава нека појава по правилу именована глаголском именицом или њеном синтагмом (уп.: ступање на дужност; почетак градње, предлог министра, потписивање споразума, срамна одлука итд.).

\subsection{3. НА РАЧУН $+\Gamma / /$ ПРОТИВ $+\Gamma$}

У српском језику у употреби је врло честа опозитна генитивна синтагма с предлошким изразом на рачун. У синтагмама с тим предлошким изразом увијек се надређеним чланом изражава различито лексичкосемантички или синтагматски градиран „негативни став или реаговање” о неким неексплицираним карактеристикама онога што је обиљежено именицом у генитиву. Уз овај предлошки израз долазе готово искључиво ${ }^{5}$ конкретне именице у генитиву, именице којим се експлицитно или метонимијски означава човјек односно људи, чему је вјероватно разлог потпуно нераскинута веза метафоричког с конкретним значењем именице „рачун”. У надређеном члану синтагме долазе искључиво глаголске именице „негативног става или реаговања” (оптужба, увредливе речи, критике, увреде, негативан коментар, погрда и сл.):

(3) Надал је изјавио да је циљ тужбе да јавне личности не износе увреде или лажне оптужбе на рачун [ $\rightarrow$ против] спортиста. (Политика, 26. 4. 2016, 31); Желим да спречим сваку јавну личност да износи лажне оптужбе против [ $\rightarrow$ на рачун] спортиста. (Вечерње новости, 26. 4. 2016, 37); ...присталице су извикивале увредљиве речи на рачун [ $\rightarrow$ против] победника (Вечерње новости, 11. 5. 2016, 18); Ни данас нећу изговорити ниједну лошу и непристојну реч на рачун [ $\rightarrow$ против] Хрватске и њених грађана - рекао је Вучић. (Вечерње новости, 11. 9. 2016, 4); Да ли су отужбе на рачун [ $\rightarrow$ против] Републике Српске послужиле Хрватској као начин да непријатне теме ... свали у суседно двориште? (Политика, 24. 5. 2016, 4); Оптужбе против [ $\rightarrow$ на рачун] Акуне су озбиљне (Политика, 4. 2. 2016, 2); Он је том приликом изнео и критике на рачун [ $\rightarrow$ против] Немаца (Политика, 31. 5. 2016, 3); Британка Анабел Нари морала да укине негативни коментар на рачун [ $\rightarrow$ против] грађевинске фирме због наводног непоштовања закона (Политика, 27. 5. 2016, 20: поднаслов); И ове године сте, као и прошле, пред Саветом безбедности УН изнели оштре критике на рачун [ $\rightarrow$ против] РС и њеног председника Милорада Додика (Политика, 29. 5. 2016, 2); Сукоб је тињао неколико дана, откако је Дијана Вукомановић јавно изјавила да би Петровићева требало да се извини због вулгарних увреда на рачун [ $\rightarrow$ против] једне новинарке (Вечерње новости, 22. 6. 2016, 3); ...где је

${ }^{5}$ Ово „готово” због сљедећег једној јединог у корпусу забиљеженог примјера с глаголском именицом: ....само је питање времена када ће они научити да прихватају критике $и$ на рачун [ $\rightarrow$ против] свог рада (Вечерње новости, 23. 7. 2016, 4). 
Уго Чавез одржава стабилност путем личног, сировог ореола популисте и ауторитаризма који је био ојачан погрдама против [ $\rightarrow$ на рачун] Сједињених Држава. (Политика, 29. 7. 2016, 14); Најбруталније увреде опозиције на рачун [ $\rightarrow$ против] Скупштине и Владе наставиће се све док се поново не дочепају прилике да поново пљачкају државу. (Вечерње новости, 12. 8. 2016, 3);

\subsection{4. НА ШТЕТУ $+\Gamma / /$ ПРОТИВ $+\Gamma$}

У литератури се генитивни предлошки изрази на рачун и на штету карактеришу као изрази којим се изражава „повољност и неповољност” (Поповић 1966: 207), очито је да се оба ова израза користе за означавање „неповољности”. Иако се реализација оба израза остварује с готово подударним лексичкосемантичким карактеристикама надређеног и подређеног члана синтагме, ипак ти изрази, кад се посматрају у суодносу са конкурентним предлогом против, по правилу нису међусобно замјењиви. То је вјероватно разлог што се предлошким изразом на рачун исказује директни „негативни став или реаговање", док је предлошки израз на штету према критеријуму (ин)директности необиљежен. У синтагмама с предлошким изразом на штету зависним чланом синтагме увијек се обиљежава штетна посљедица реализавције појма у надређеном члану синтагме. Будући да предлошки израз на рачун не подразумијева семантичку компоненту посљедице, то је вјероватно разлог несупституентности та два блиска предлошка израза обједињена значењем „неповољности”:

(4) „У континуитету политички погрешних одлука на штету [ $\rightarrow$ против] срnског народа, ништа није изненађујуће”, рекао је Додик. (Политика, 18. 9. 2016, 2); Срби стрепе да ће велике западне силе уз помоћ сарајевских извршитеља покушати да изведу још једну алхемијску режију на штету [ $\rightarrow$ против] нашег народа. (Вечерње новости, 5. 10. 2016, 4); Вашингтом потпаљује Балкан, уз помоћ ЕУ, како би деловао против [ $\rightarrow$ на штету] Русије (Вечерње новости, 4. 6. 2016, 14); ...али се прилично јасно види да нова геополитичка прекомпозиција иде на штету [ $\rightarrow$ против] украјинских интереса. (Политика, 8. 9. 2016, 1); Политички фактори из републике Српске немају ништа против уређења БиХ на начин који Човић предлаже, али под условом да то не иде на штету $[\rightarrow$ против] PC и њених изворних надлежности прописаних Дејтонским споразумом. (Политика, 17. 9. 2016, 4); и сл.

Између наведених примјера два посљедња су двоструко карактеристична. Прво, што у позицији надређеног члана не долази глаголска именица него опозитно неутралан глагол „ићи”, и друго што се конструкција глагола и предлошког израза може тумачити и као декомпоновани предикат: иде на штету украјинских интереса [ $\longleftarrow$ штети украјинским интересима]; не иде на umemy $\mathrm{PC}[\leftarrow$ не итети $\mathrm{PC}]$.

${ }^{6}$ „Повољност и неповољност: $у$ корист $+\Gamma ;$; прилог $+\Gamma ;$ у интересу $+\Gamma$; на штету $+\Gamma$; на уштрб $+Г$; на рачун $+\Gamma^{\prime}$. (Поповић 1966: 207). 


\subsection{5. НА АДРЕСУ $+\Gamma / /$ ПРОТИВ $+\Gamma$}

Забиљежили смо само један примјер предлогу против конкурентног, у литератури незабиљеженог, генитивног предлошког израза на адресу. А ријеткост употребе овог израза је разумљива, пошто је он синониман врло раширеном генитивном предлошком изразу на рачун, па се може сматрати његовом „стилском резервом”:

(5) Оптужбе на адресу [ $\rightarrow$ против] руских спортиста подигнуте су на исказима једног човека. (Политика, 19. 7. 2016, 34).

\subsection{6. ОД + Г // ПРОТИВ $+\Gamma$}

Генитивном синтагмом с предлогом од ретко се изражава опозитно значење, провјерљиво замјењивошћу дате синтагме генитивном синтагмом с предлогом против. Генитив с предлогом од има значење опозитности, и замјењив је увијек генитивом с предлогом против, у синтагмама с именицама са значењем ,лијека”. У тим синтагмама у савременом српском језику готово искључиво се употребљава или генитив с предлогом против, или акузатив с предлогом за, док генитивне синтагме с предлогом од (које и овдје потврђујемо примјером из језика Љубе Ненадовића) имају архаичан призвук:

(6) Пронашли су да је кинин лек од [ $\rightarrow$ против] грознице (Ковачевић 1983: 108, Љ. Ненадовић)

\subsection{7. ПОСЛ(ИЈ)Е + Г // ПРОТИВ + Г}

Генитивни предлог посл(иј)е и његов синоним након у свим контекстима као примарно имају временско значење. То значење се у појединим контекстима може комбиновати са опозитним значењем ако се надређеним чланом изражава у односу на релизацију појма у генитиву постериорна акција чији је циљ управо неутралисање или оспоравање тог генитивног појма, будући да се он схвата и као разлог предузимања дате акције „непријатељског дјеловања”. Опозитно значење у овој се синтагми темељи на закључивању типа post hoc, ergo propter hoc.

(7) Тачно је, побунила сам се после [ $\rightarrow$ против] юене изјаве да је НАЛЕД најзаслужнији што је Србија напредовала на листи Светске банке. (Блиц, 31. 12. 2017. - 2. 1. 2018, 24).

\section{2. Дативне падежне и предлошко-падежне форме са опозитним значењем}

У одређеним контекстима како датив с предлозима према и ка тако и беспредлошки датив могу се супституисати генитивом с предлогом против као верификатором опозитног значења. 


\subsection{1. ПРЕМА + Д // ПРОТИВ + Г}

Дативним опозитним синтагмама с предлогом против обиљежава се „одбојност што је агенс има према лицу или предмету означеном детерминантом синтагме” (Ковачевић 2012: 159). А „одбојност”, која је препознатљива по семантици надређеног члана синтагме, испољава се на два начина: а) или као „негативан став” (нагативан став, мржна, отпор, хистерија, алергичност, непримерена реторика и сл.) или као „негативан поступак” према ономе што је обиљежено дативном именицом (санкције, оштрије мере, фајтерски однос, насиље, злочин и сл.):

(8) Не могу да се помирим са таквим негативним ставовима према Србима $[\rightarrow$ против Срба] (Вечерње новости, 12. 10. 2016, 3); Међу најављеним мерама су санкције према руским обавештајним агениијама [ $\rightarrow$ против руских обавјештајних агенција] ФБС и ГРУ (Политика, 30. 12. 2016, 3); ...а алабански и хрватски навијачи суз навијали, то јест изливали анималну мржњу против Срба [ $\rightarrow$ према Србима] (Блиц, 9. 10. 2016, $2) ;$...овде се избори не добијају мржњом према бивщој браћи [ $\rightarrow$ против бивще браће]. (Вечерње новости, 3. 10. 2016, 3); Хозеа и његовог издавача Петера Зуркампа ујединио је заједнички отпор према нацизму [ $\rightarrow$ против нащизма]. (Политика, 7. 6. 2016, 13); Мељник је на основу те спекулације затражио од Немачке да заузме оштрији став према Русији $[\rightarrow$ против Русије]. (Вечерње новости, 18. 8. 2016, 8); Он у писму тражи од ње да нађе начин да „смири неконтрролисану хистерију према Београду" [ $\rightarrow$ против Београда] (Блиц, 23. 7. 2016, 7); Кажњен због непримерене реторике према Србији $[\rightarrow$ против Србије] (Вечерње новости, 12. 9. 2016, 10: наслов); Јовановић, опет, своју платформу гради на фајтерском односу према режиму [ $\rightarrow$ против режима] (Политика, 12. 10. 2016, 5); Оштрије мере према мигрантима [ $\rightarrow$ против миграната] (Вечерње новости, 14. 9. 2016, 3: наслов); Из исказа сведока не произилази да је умишљај пријављених био уперен ка томе да врше насиље према другом [ $\rightarrow$ против другог]. (Блиц, 19. 11. 2017, 2); Ако је неко помислио да би низ показивања сталних алергичности према свему $[\rightarrow$ против свега] са српским призвуком, из Сарајева напокон могао заменити стисак руке.... (Политика, 11. 2. 2017, 5); А то је злочин према фудбалској игри [ $\rightarrow$ против фудбалске игре] (Политика, 12. 7. 2016, 35) и сл.

\subsection{2. КА + Д// ПРОТИВ + Г}

У само једном једином примјеру као потпуни синоним дативном предлогу према употријебљен је дативни предлог ка, и то вјероватно због специфиног структурисања реченице у којој је предлог дошао иза глагола усмерености (биће окренута) чију семантичку компоненту као најзначајнију и сам садржи, а заправо се синтагмом с тим предлогом образлаже разлог љутње, чији је (не)посредни изазивач означен именицом у дативу:

(9) ...оштрица америчке љутње биће окренута ка њиховим најближим савезнииима [ $\rightarrow$ против најближих савезника]. (Вечерње новости, 23. 12. 2017, 3). 


\subsection{3. ØД // ПРОТИВ + Г}

Од свих беспредлошких падежа дативом је „најподобнији” за обиљежавање опозитног значења. У позицији надређеног члана синтагме тада долази нека језичка јединица која означава „негативан поступак” агенса према експлицитно, деиктички или метонимијски именованом човјеку или људима означеним дативом, а због неексплицираних а за дативни појам везаних разлога (санкције, критика, отпор, противљење, пресуда и можда још која):

(10) Има ли демократије у земљи у којој се свака критика власти $[\rightarrow$ против власти] сматра државним ударом. (Данас, 26. 7. 2016, 2); Чуме се томе [ $\rightarrow$ против тога] успротивио. (Информер, 20. 1. 2016, 12); САД и Кина договориле резолуцију о санкцијама Северној Кореји [ $\rightarrow$ против Северне Кореје] (Политика, 25. 2. 2016, 2: наслов); Украјинска влада је јуче проширила листу санкција против руских појединаца и компанија $[\rightarrow$ руским појединцима и компанијама] (Политика, 21. 1. 2016, 3); У обраћању Хагу, наше власти ће предочити да би хапшење Шешеља и изрицање пресуде против њега [ $\rightarrow$ њему] могло да изазове политичку нестабилност у држави. (Вечерње новости, 15-16. 2. 2016, 3); Приштина прети санкцијама Србији [ $\rightarrow$ против Србије] (Вечерње новости, 26. 2. 2016, 7: наслов); Једнини нисмо увели санкције Русији [ $\rightarrow$ против Pусије] (Вечерње новости, 7. 3. 2016, 3); Отпор против оних [ $\rightarrow$ онима] који су издали земљу (Политика, 27. 3. 2016, 16: наслов); Током минулог викенда, у Загребу је боравио и славни француски филозоф Ален Финкелкраут с циљем да пружи подршку хрватским грађанима у отпору протиє министра културе [ $\rightarrow$ министру културе] Златка Хасанбеговића. (Вечерње новости, 6. 6. 2016, 10); Чувени писац из Ниша каже да је пресуда против њега [ $\rightarrow$ њему] безакоње (Политика, 19. 5. 2016, 7: поднаслов); и сл.

\section{3. Акузативне предлошко-падежне форме с опозитним значењем}

Само се акузативом с предлозима на и за у одређеним контекстима може изразити и опозитно значење, верификовано могућношћу замјене датих предлога чисто опозитним генитивним предлогом против као синонимом.

$$
\text { 2.3.1. НА }+ \text { А // ПРОТИВ }+ \text { Г }
$$

Опозитним синтагмама с предлогом против, осим примарно узрочних синтагми с предлогом због и предлошким изразом поводом, најчешће су конкурентне и у употреби врло честе акузативне синтагме с предлогом на. Ове синтагме имају специфичну лексичкосемантичку структуру. У управном члану синтагме тако долазе глаголи, глаголске именице или перифрастички изрази са општим значењем „оштрог реаговања”, па чак и физичког (azpecuja, офанзива, харанга, жалба, тужба, протестна нота, напад, оштре речи и сл.), док зависну позицију заузима конкретна или глаголска именица којим се именују конкретно или метонимијски препознатљиво лице или појава за које су везани неексплицрани разлози због којих је и дошло до реаговања, које за циљ има уништење или појма обиљеженог зависним чланом или пак разлога за њ везаних: 
(11) Политика би разумела Милана Антонијевића и његове колеге да је наш лист заиста водио харангу на невладине организачије [ $\rightarrow$ против невладиних организаиија] запаљивом реториком и увредљивим оптужбама. (Политика, 23. 1. 2016, 5); Тужилаштво је навело да ће се жалити на овакву одлуку [ $\rightarrow$ против овакве одлуке] судије. (Политика, 1. 6. 2016, 9); Врховни суд Турске одбио жалбу опозиције на референдум [ $\rightarrow$ протиє референдума] (Данас, 26. 4. 2017, 17: наслов); Из Ристићеве адвокатске канцеларије најављују жалбу против пресуде [ $\rightarrow$ на пресуду] (Политика, 19. 5. 2016, 7); Упитан како то да он ... подноси тужбу на одлуку [ $\rightarrow$ против одлуке] УЕФА, Лански одговара да он не мора да се понаша као земља чији је држављанин. (Политика, 29. 6. 2016, 31); Фалсификовани извештај с терена у Рачку био је повод за директну војну агресију на Србију [ $\rightarrow$ против Србије] (Вечерње новости, 4. 6. 2016, 35); У мају је кијевски суд након две године разматрања одлучио да није било „агресије” Русије против Украјине [ $\rightarrow$ на Украјину] (Политика, 26. 8. 2016, 15); ... надомак Мосула ... се припрема офанзива против Исламске државе [ $\rightarrow$ Исламску државу] (Политика, 30. 12. 2015, 3); Чомски додаје како је Ердоган потом осуо бујицу оштрих речи против оних [ $\rightarrow$ на оне] који осуђују његове злочине над Курдима (Вечерње новости, 16. 1. 2016, 8); Протестном нотом на бахатост $[\rightarrow$ протиє бахатости] Хашког трибунала (Политика, 11. 2. 2016, 5: наслов); Дик Паунд укључио се у „хајку” на [ $\rightarrow$ против] најбољег тенисера света Новака Ђоковића (Политика, 23. 4. 2016, 27); И бивши председник ВАДА се укључио у „хајку” против [ $\rightarrow$ на] Ђоковића (Политика, 23. 4. 2016, 27: наслов); ...а ми нисмо могли да уложимо приговоре на решење $[\rightarrow$ против решења] које никада нисмо добили (Вечерње новости, 14. 5. 2016, 5); ...они лако грме против [ $\rightarrow$ на] противника (Вечерње новости, 11. 5. 2016, 18); Председник Српске наводи да се у претходном периоду оркестрирано кренуло на Републику Српску $[\rightarrow$ против Републике Српске] (Српски телеграф, 1. 6. 2016, 6); Министарство је ту пријаву и документацију третирало као притужбу на рад $[\rightarrow$ против рада] судског вештака. (Данас, 9. 8. 2016, 11); Хрватски министар оптужује званичнике Србије да циљано шире осећај освете, хушкају српски народ против других [ $\rightarrow$ на друге] (Вечерње новости, 9. 8. 2016, 2); ...нервозно реагује на сваку јавну критику [ $\rightarrow$ против сваке јавне критике] (Политика, 25. 7. 2016, 23); Градоначелник Синиша Мали изјавио је да су напади на њега политичке природе и у ствари усмерени против [ $\rightarrow$ на] премијера Александра Вучића. (Политика, 4. 11. 2015, 17); У међувремену, све је више негативних реакција на изјаве $[\rightarrow$ против изјава] бившег премијера Хрватске (Политика, 27.8. 2016, 1); Кућа људских права осудила медијске нападе на Независно друштво новинара Војводине $[\rightarrow$ протиє Независног друштва новинара Војводине] (Данас, 15-16. 2. 2016, 8: наднаслов); и сл.

\subsubsection{3А + А // ПРОТИВ + Г}

Значење „непријатељског дјеловања”, које је основно значење предлога против, увијек подразумијева, мање или више потиснуто у други план, и значење намјене. Наиме, сврха предузимања непријатељског дјеловања јесте неутралисање или уништење онога што је обиљежено именицом у зависном члану синтагме. На тај начин сусрећу се значења предлога против као основног опозитног предлога и акузативног предлога за као основног предлога за обиљежавање намјене. Та су два предлога међусобно замјењива увијек у синтагмама „код којих у централној позицији долазе лексеме које означавају неко 'средство за спречавање, сузбијање' онога што је именовано у зависној позицији синтагме. У централној позицији ових синтагми најчешће су лексеме које имају опште значење лијека, док зависну позицију заузимају лексеме са 
значењем неке болести" (Ковачевић 1983: 108). А лијек служи као средство за ,заштиту” од болести (тада је примарно рјешење акузативни предлог за са значењем намјене) и као средство „елиминисања” болести (када је примарно рјешење предлог против са значењем „непријатељског дјеловања”). Тај тип односа остварује се у свим атрибутским синтагмама у којима надређена именица, и изван лијека, има значење „средство за спречавање или сузбијање” онога што се означава генитивом (нпр. ракете, глогов колаи у нашим примјерима). У корпусу смо забиљежили још само примјере с именицама пријава, оптужница и закон, које већ у својој семичкој структури подразумијевају и значење намјене и значење „непријатељског дјеловања”, па је логично што се уз њих као блискозначни употребљавају генитивни предлог против и акузативни предлог за:

(12) Али ми немамо ракете за те облаке [ $\rightarrow$ против тих облака]. (Политика, 1. 8. 2016, 13); За очигледно повампирење фашизма [ $\rightarrow$ против очигледног повампирења фашизма] уснула Европа нема глогов колац (Вечерње новости, 29. 7. 2016, 2); Имамо лек за псоријазу [ $\rightarrow$ против псоријазе] (Курир, 12. 1. 2009, 14); Цртање је најбољи лек за бол [ $\rightarrow$ против бола] (Вечерње новости, 29. 4. 2016, 33: наслов); Први пацијенти из Војводине у понедељак ће примити кубанску вакцину против рака [ $\rightarrow$ за рак]. (Вечерње новости, 21. 1. 2016, 5); Медени напитак против упала [ $\rightarrow$ за упале] (Вечерње новости, 29. 4. 2016, 32: наслов); Кривична пријава за [ $\rightarrow$ против] возача који је ударио две ученице на прелазу и побегао (Политика, 20. 1. 2016, 14: наслов); Кривичне пријаве за [ $\rightarrow$ против] Бакира Изетбеговића и Сакиба Софтића упућене су јуче поштом Тужилаштву БиХ у Сарајеву (Вечерње новости, 14. 3. 2017, 8); Британски премијер ... најавио строге законе против оних [ $\rightarrow$ за оне] који таје порез (Политика, 12. 4. 2016, 3); Спремамо оптужнице за хрватске злочине [ $\rightarrow$ против хрватских злочина] (Вечерње новости, 5 . 8. 2016, 3: наслов); и сл.

\section{4. Инструменталне падежне и предлошко-падежне форме са опозитним значењем}

Нереципрочно опозитно значење може се изразити како беспредлошким инструменталом тако и инструменталом с предлозима са и над и предлошким изразом у вези са, с тим да се предлошки опозитини инструментал много чешће употребљава од беспредлошког и „предлошкоизразног”.

$$
\text { 2.4.1. СА }+ \text { И // ПРОТИВ }+ \text { Г }
$$

У синтагмама реципрочене опозитности инструментални је предлог $c a$ готово у свим контекстима конкурентан генитивном предлогу против (Ковачевић 2017: 129-155). Међутим, у синтагмама нереципрочне опозитности, које су предмет овог рада, инструментални предлог са доста се ријетко употребљава, и то по правилу уз мали број глаголских или именичких лексема са значењем „сукоба” (борити се, борба, рат, обрачун и сл), с тим да је, за разлику од синтагми реципрочне опозитности, овдје зависним чланом увијек означена нека појава: 
(13) Боримо се против снега [ $\rightarrow$ са снегом], не престајемо! (Политика, 5. 1. 2016, 17); Организујте борбу против сваког облика националног угњетавања $[\rightarrow$ са сваким обликом националног угњетавања] са стране српских зулумћара (Политика, 21. 7. 2016, $24) ;$ Како се „Оптимисти” боре против сиромаштва [ $\rightarrow$ са сиромаштвом] (Политика, 8. 8. 2016, 14: наслов); Девет деценија борбе са заразама и предрасудама [ $\rightarrow$ против зараза и предрасуда] (Политика, 16. 12. 2016, 7: наслов); Реалов везиста ... већ дуже време је у рату са медијима [ $\rightarrow$ против медија] због лоших игара. (Вечерње новости, 28. 3. 2017, 39); Економисти указују како реформе морају да се усмере у обрачун са сивом економијом [ $\rightarrow$ против сиве економије] (Политика, 20. 2. 2017, 4); Једна од најбољих кошаркашица борила се годинама $c$ повредама [ $\rightarrow$ против повреда] (Блиц, 27.8. 2016, 40); Борио се $c$ ретком болешћу [ $\rightarrow$ против ретке болести] (Пипер, Клајн 2013: 385) и сл.

У литератури је поводом конкурентности ова два предлога већ уочено да се у појединим примјерима успоставља прагматичка диференцијација. Констатовано је тако да „када се говори о болестима(,) обе наведене конструкције су исправне, али између њих постоји извесна разлика у употреби: Борио се с болешћу пре би се рекло за болесника, а Борио се против болести за неког здравственог радника, научника и сл.” (Пипер, Клајн 2013: 385) .

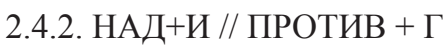

Опозитном инструменталним синтагмама с предлогом над увијек се изражава значење „насилништва”. То значење основно је значење глаголских именица које долазе у позицији надређеног члана ових синтагми, а то су, како наш корпус показује: насиље, геноцид, погром, злочин и тортура. Вршење „насилништва” за циљ увијек има уништење онога је означено именицом у инструменталу:

(14) Потврђена оптужница за злочине над Србима $[\rightarrow$ против Срба] из Завидовића (Политика, 8. 1. 2016, 4: наслов); ...почело је суђење за злочин над српским заробљенииима $[\rightarrow$ против српских заробљеника] у селима општине Сребренице и Братунац. (Политика, 27. 1. 2016, 1); Сваки злочин против Срба [ $\rightarrow$ над Србима] могао је бити решен да је постојала добра воља. (Вечерње новости, 7. 2. 2016, 3); Џихадистичка група Исламска република чини геноцид против хришћана [ $\rightarrow$ над хришћанима] (Политика, 18. 3. $2016,3)$; ...да је Андрић у босанској федерацији проглашен инспиратором погрома над Бошъацима [ $\rightarrow$ против Бошњака]. (Политика, 15. 4. 2016, 25); Насиље против мањина [ $\rightarrow$ над мањинама] - геноцид (Политика, 21. 4. 2016, 4: наслов); Са друге стране та силна силовања на сцени, стално насиље над женама. (Политика, 23. 3. 2016, 13); Власти у Приштини спроводе тортуру над запосленима $[\rightarrow$ против запослених] у привременим органима општина (Вечерње новости, 12. 7. 2016, 2); и сл.

\subsection{3. У ВЕЗИ СА + И // ПРОТИВ + Г}

Кад је конкурентан предлогу против, инструментални предлошки израз y вези са увијек има значење повода, тако да је замјењив предлошким генитивним изразом поводом као потпуним синонимом (Ковачевић 2012: 170-171). А будући да је предлошки израз поводом врло чест у употреби, није ни чудно 
што његов синоним у вези са као „стилска резерва” нема ширу употребу у овом значењу:

(15) Министарство одбране Србије одбацило је синоћ критике Војног синдиката Србије у вези са постављењима [ $\rightarrow$ против постављења] у Министарству одбране и Војсци Србије (Политика, 9. 1. 2016, 8).

\subsection{4. ØИ // ПРОТИВ + Г}

На основу корпуса и литературе може се закључити да се беспредлошким инструменталом најрјеђе изражава опозитно значење, провјерљиво могућношћу замјене беспредлошког инструментала генитивом с предлогом против. У нашем корпусу нисмо забиљежили ниједан примјер овог типа инструментала, али је у литератури забиљежен један примјер опозитног беспредлошког инструментала замјењивог генитивом с предлогом против, уз именицу незадовољсто:

(16) ...али појава незадовољства аграрним односима [ $\rightarrow$ против аграрних односа] било је и код хрватског становништва (Ковачевић 2012, 191: Х. Капиџић).

Не треба да чуди ријеткост овог типа инструментала у опозитном значењу кад се зна да се уз именицу незадовољство, као много фреквентнији у употреби сусрећу и генитив с предлогом против и датив с предлогом према (в. Ковачевић 2012:191).

\section{3. Локативне предлошко-падежне форме с опозитним значењем}

Од свих локативних предлошко-падежних форми у нашем су корпусу забиљежени само примјери локатива с предлогом $о$, коме се значење може, прије свега на основу могућности супституције генитивним предлогом против као синонимом, тумачити и као опозитно.

\subsection{1. О+Л // ПРОТИВ + Г}

Локатив с предлогом о долази „уз једну одређену врсту глаголских односно именичких лексема”, уз „тзв. глаголе говорења и мишљења (у широком смислу)" (Батистић 1972: 43) и с њима семантички повезане (најчешће, али не и нужно) глаголске именице. Уколико се глаголом или глаголском именицом као надређеним чланом синтагме изражава неки „негативан став” (типа замјерке, критике, лагања, замешатељства и сл.) и ако је такав став условљен никад неекслицираним разлогом везаним за лице обиљежено локативном именицом - стичу се услови да се локативна синтагма с предлогом $о$ протумачи и у опозитном значењу, посебно и зато што је она тада замјењива генитивом с предлогом против као верификатором опозитног значења, као нпр.: 
(17) Понекад у њима [тим новинама] може да се нађе неки веома критичан текст против неког из владе [ $\rightarrow$ о неком из владе], о неком министру или члану $[\rightarrow$ против наког министра или члана] владајуће коалиције, али никад против Вучића [ $\rightarrow$ о Вучићу]. (Данас, 21. 7. 2016, 10); Тужиоци су покренули истрагу о академицима [ $\rightarrow$ против академика] због могућих оптужби за вређање државе. (Политика, 17. 1. 2016, 3); Антонић у „Делта Времену" никада неће написати ни једну реч против Мииковића [ $\rightarrow$ о Мишковићу]. (Политика, 12. 7. 2016, 26); Већина дневних новина лаже против мене [ $\rightarrow$ о мени] (Политика, 20. 2. 2017, 6: наслов); Адвокатске коморе Београда и Војводине скупљају доказе против лидера [ $\rightarrow$ о лидеру] Коморе Србије (Вечерње новости, 1. 6. 2016, 4); Дође колега из Словачке који овде дуго живи такође апсолутно уверен да је све то део замешатељства против Ђоковића [ $\rightarrow$ о Боковићу]. (Политика, 24. 1. 2016, 34); и сл.

\section{3. СИНОНИМНОСТ ТРИЈУ ИЛИ ВИШЕ ОПОЗИТНИХ ПАДЕЖНИХ ФОРМИ}

У досадашњој анализи разматрани су само двојни односи опозитних предлога, из чега би се могло, погрешно, закључити да само по двије падежне форме могу бити синонимне или блискозначне при изражавању опозитног значења. Такав би закључак, међутим, био нетачан, зато што у односу синонимности или блискозначности може бити три и више падежних форми. Будући да су у претходном дијелу рада дата најбитнија освјетљења сваког од опозитних модела падежних синтагми, овдје ћемо навести најприје синонимски петочлани, па четворочлане, и на крају трочлане моделе поткријепљене само са по једним примјером.

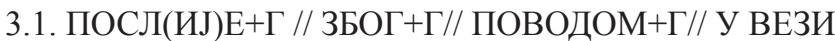 СА + И // ПРОТИВ $+Г$}

Ових пет синтагматских модела имају блискозначно опозитно значење и међусобно су замјењиви само кад се посматрају из перспективе модела ПОСЛ(ИЈ)Е $+Г$. Јер, у свим случајевима у којима примарно временска генитивна синтагма с предлогом посл(uj)e има као саприсутно а равноправно и опозитно значење, та је синтагма замјењива четирима осталим, док правило о обрнутој супституентности не важи. То значи да опозитни модел генитивне синтагма с предлогом посл(uj)e има мању творбену плодност и могућност много уже дистрибуције од остала четири модела.

(18) Побунила сам се после $[\rightarrow$ против/због/ поводом] такве њене изјаве $[\rightarrow y$ вези с таквом неном изјавом]. 


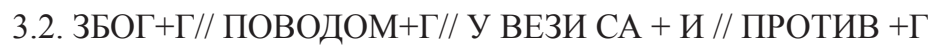

Уз већи број лексема са општим значењем „протеста” четири неведене падежне конструкције међусобно су земјењиве у опозитном значењу, с тим да је најрјеђа у употреби инструментална:

(19) Организовали су протест против [ $\rightarrow$ због/ поводом] изградње пумпе [ $\rightarrow y$ вези са изградњом иркве].

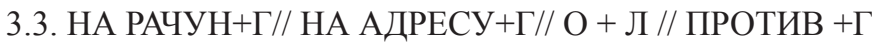

Ова четири падежна модела међусобно су замјењива уз именице „негативног става", типа критика, оптужба, негативан коментар, погрда и сл.

(20) Написао је негативан текст, а заправо критику против [ $\rightarrow$ на рачун/на адресу] владе [ $\rightarrow$ влади].

\subsection{3А+А// ОД+Г// ØД // ПРОТИВ + Г}

Уз именице са значењем „лијека” међусобно су супституентне четири наведене падежне и предлошко-падежне конструкције, с тим да се генитивна конструкција с предлогом од најрјеђе употребљава јер се у савременом језику осјећа као архаична:

(21) Нема ијека тој болести [ $\rightarrow$ од/против те болести // за ту болест].

\section{5. ØД // ПРЕМА+Д // ПРОТИВ + Г}

Наведена три падежна опозитна модела конкурентна су кад је у позицији надређеног члана употријебљена именица санкције или отпор, као нпр.:

(22) САД одлучиле да продуже санкције Русији [ $\rightarrow$ према Русији // против Русије]; На сваком кораку осјећа се отпор страној агресији [ $\rightarrow$ према страној агресији // против стране агресије].

\section{6. ПРЕМА+Д // НАД+И // ПРОТИВ + Г}

Наведене предлошко-падежне конструкције могу се као синоними употријебити уз именице којима се означава „насилништво”: бима].

(23) Било је много насиља и злочина против Срба [ $\rightarrow$ према Србима // над Cp- 


\section{7. ПРЕМА+Д // ØИ// ПРОТИВ + Г}

Једино уз именицу незадовољьство јавља се опозитни беспредлошки инструментал, с тим да је он тада замјењив дативном конструкцијом с предлогом према и верификативно опозитном генитивном конструкцијом с предлогом против:

(24) На сваком кораку се осјећало незадовољство аусторугарском окупацијом [ $\rightarrow$ према аустроугарској окупачији // против аустроугарске окупације].

\section{4. ЗАКЉУЧАК}

4.1. У раду су на богатом корпусу из новинарског подстила публицистичког стила савременог српског језика, пописани и описани модели падажних синтагми којима се у српском језику може изразити нереципрочно опозитно значење. Анализа је показала да се свим предлошким зависним падежима српскога језика може изразити опозитно значење, док од беспредлошких падажа само датив и инструментал изражавају опозитно значење.

4.1.1. Генитив од свих падежа има највише опозитних предлошко-падежних форми. Основној опозитној падежној форми - генитиву с предлогом против - у одређеним контекстима синонимне и/или блискозначене могу бити синтагме са седам генитивних предлога и предлошких израза: због, поводом, на рачун, на штету, на адресу, од и посл(иј)е.

4.1.2. Опозитно значење се у одређеним контекстима може изразити како дативом с предлозима према и ка тако и беспредлошким дативом.

4.1.3. Од акузативних предлошких форми само се оним с предлозима на и з $a$ у одређеним контекстима може изразити опозитно значење.

4.1.4. Послије генитива највише контекстуално условљених опозитних форми има инструментал. Нереципрочно опозитно значење може се изразити како беспредлошким инструмрнталом тако и инструменталом с предлозима $c a$ и над и предлошким изразом у вези $c a$.

4.1.5. У погледу опозитних форми најсиромашнији је локатив. Само се локативом с предлогом $о$ у одређеним контекстима може изразити опозитно значење.

4.2. Анализа је показала да осим „двоструких” синонимских односа постоји и „вишеструка” синонимија опозитних модела, која укључује синонимност три, четири или чак пет падежних опозитних модела. 


\section{ИЗВОРИ}

Блиц - Blic, dnevne novine iz Beograda.

Вечерње новости - Вечерње новости, дневне новине из Београда.

Данас - Danas, dnevne novine iz Beograda.

Информер - Informer, dnevne novine iz Beograda.

Курир - Kurir, dnevne novine iz Beograda.

Печат - Печат, седмичне новине из Београда.

Политика - Политика, дневне новине из Београда.

Српски телеграф - Srpski telegraf, dnevne novine iz Beograda.

\section{ЛИТЕРАТУРА}

Батистић 1972: Tatjana Batistić, Lokativ u savremenom srpskohrvatskom književnom jeziku, Beograd: Institut za srpskohrvatski jezik.

Клајн, Шипка 2008: Иван Клајн, Милан Шипка, Велики речник страних речи и израза, Нови Сад: Прометеј.

Ковачевић 1983: Miloš Kovačević, Nekolika značenja padežnih atributa, Jezik XXX/4, Zagreb, 107-112.

Ковачевић 1987: Милош Ковачевић, Узрочно значење синтагми с приједлогом ПРОТИВ, Књижевни језик, XVI/3-4, Сарајево, 189-195.

Ковачевић 2012: Милош Ковачевић, Узрочно семантичко поље, II издање, Београд: Јасен.

Ковачевић 2017: Милош Ковачевић, Опозитни генитив с предлогом ПРОТИВ и синонимске падежне конструкције, Српски језик под лупом науке, Београд: Завод за уџбенике, 129-155.

Пипер и др. 2005: Предраг Пипер, Ивана Антонић, Владислава Ружић, Срето Танасић, Људмила Поповић, Бранко Тошовић, Синтакса савременога српског језика: проста реченица, у редакцији Милке Ивић, Београд: Институт за српски језик САНУ, Београдска књига; Нови Сад: Матица српска.

Пипер, Клајн 2013: Предраг Пипер, Иван Клајн, Нормативна граматика српског језика, Нови Сад: Матица српска.

Поповић 1966: Љубомир Поповић, Предлошки изрази у савременом српскохрватском језику, Наш језик, XV/3-4, 195-220. 
PMC 1971: Речник српскохрватскога књижевног језика, књ. 4, Нови Сад: Матица српска.

Силић, Прањковић 2005: Josip Silić, Ivo Pranjković, Gramatika hrvatskoga jezika za gimnazije i visoka učilišta, Zagreb: Školska knjiga.

Стевановић 1979: Михаило Стевановић, Савремени српскохраватски језик (граматички сиетеми и књижевнојезичка норма) II Синтакса, III издање, Београд: Научна књига.

Фелешко 1995: Казимијерж Фелешко, Значењ а и синтакса српскохрватског генитива, Београд: Вукова задужбина; Нови Сад: Матица српска, Орфелин, 149-151.

Хјелмслев 1980: Louis Hjlmslev, Prolegomena teoriji jezika, prevod s njemačkog Ante Stamać, Zagreb: GZH, BiblitekaTeka.

\section{THE SYNONYMITY OF CASE CONSTRUCTIONS OF OPPOSITENESS IN SERBIAN}

\section{Summary}

Examining an ample corpus of the journalistic subregister of the publicistic register in contemporary Serbian, the paper catalogues and describes the models of case phrases which can express a non-reciprocal opposite meaning in Serbian. The analysis of those constructions was conducted by means of the synonym-distributional method, which implies that the paper identifies and describes the contexts allowing the substitutability of a case form with the genitive + preposition protiv (against) as a prototypical and verifying oppositeness form.

The analysis has demonstrated that all prepositional oblique cases in Serbian can express an opposite meaning, whereas among the non-prepositional cases only the dative and instrumental express an opposite meaning. Of all the prepositions, only the genitival preposition protiv is a contextually unconditioned opposite preposition, while all the other prepositions and complex prepositions, which amount to fifteen in our analysis (noting that two non-prepositional case constructions should be added to them) have a contextually conditioned opposite meaning. The contextual conditionality can be seen in the interrelation of lexico-semantic features of the head and modifier in the phrase.

The analysis has also demonstrated that apart from "double", there is a multiple synonymy of the opposite models, which includes the synonymity of three, four or as many as five case opposite models.

Keywords: case constructions, meaning of oppositeness, non-reciprocal oppositeness, synonymity 